\title{
Precarious Work and Mental Health among Young Adults: A Vicious Circle?
}

\author{
Anja Umičević \\ University of Primorska, Slovenia \\ anja.umicevic@gmail.com \\ Ana Arzenšek \\ University of Primorska, Slovenia \\ ana.arzensek@fm-kp.si \\ Valentina Franca \\ University of Ljubljana, Slovenia \\ valentina.franca@fu.uni-lj.si
}

An increasing number of studies and practical experience confirm that employment quality and security affect the mental and physical wellbeing of workers. This applies even more to those who are included in precarious types of work, as these are marked by work process inclusion uncertainty and lower quality in several dimensions of work performance. The purpose of this article is, therefore, to analyse mental health self-perception in individuals who have described their work as precarious. The study involved 201 participants aged 18 to 40 years old working in Slovenia. This is one of the first studies focusing on this topic on a Slovenian sample. Results evidence that those performing precarious work report low life satisfaction, including higher depression, anxiety and emotional exhaustion symptom incidence, confirming that performing precarious work is connected with poorer emotional health indicators in young adults.

Key Words: mental health, precarious work, young adults, Slovenia

JEL Classification: I18, J79

(c) BY.SA https://doi.org/10.26493/1854-6935.19.227-247

\section{Introduction}

As most people spend a large part of their life at work, this may significantly affect their health and wellbeing. Workplaces can be an important protective factor with regard to mental health (Jeriček Klanšček, Hribar, and Bajt 2017), and supporting mental health at workplaces beneficially affects worker productivity, and the economic growth and global competitiveness of organisations and society. In recent years, we have witnessed an increase in mental illness among young individuals doing insecure types of work (Julia et al. 2017; Jonsson et al. 2020; Vancea and 
Utzet 2017). Unemployment, low pay, dangerous working conditions, insecure employment types, fixed-term contracts and part-time work have been increasing among young adults with various levels of education (Toivanen et al. 2020; Mrozowicki and Trappman 2021; Domadenik et al. 2020).

Precariousness is present in various types of work where there is a tendency to reduce costs (Forde and Slater 2006; Močnik 2010) and better enable employment flexibility (Debels 2008). Precariousness takes many forms, including lower job security, lower pay, lower social security and poorer working conditions, and studies confirm that these are harmful for individuals' mental health (Vives et al. 2011), which is the focus of our research work. Many studies highlight that work-related stress and health issues are caused by precarious work (Gash, Mertens, and Gordo 2007; Quinlan, Mayhew, and Bohle 2001). Likewise, numerous studies have demonstrated the link between non-standard forms of work and poor working conditions (Eurofound 1998; Eichhorst and Tobsch 2017); additionally, precariousness and perceived job insecurity have been associated with several adverse health (Quinlan, Mayhew, and Bohle 2001; Employment Conditions Knowledge Network 2007) and occupational safety consequences (Quinlan, Mayhew, and Bohle 2001). The list of negative health outcomes is varied and includes an increase in mental health problems, including clinical depression, health self-assessment deterioration and sleep disorders (Mai, Jacobs, and Schieman 2019), and an increase in the use of psychotropic drugs (Glavin 2013; Lam, Fan, and Moen 2014; Moscone, Tosetti, and Vittadini 2016; Virtanen, Janlert, and Hammarström 2011).

Although the use of the term precarious work has been increasing internationally, the definition of precariousness is multifaceted and remains unclear. The situation is further complicated by the fact that precariousness is defined differently, depending on the state, region, economic and social structure of political systems and labour market (Utzet et al. 2020). As a multidimensional phenomenon (Kalleberg 2014; Broughton, Green, and Rickard 2016; Jetha et al. 2020; Kreshpaj et al. 2020; Padrosa et al. 2021; Allan, Autin, and Wilkins-Yel 2021; Valero et al. 2021), operationalisation of precariousness demands a variety of methodological approaches and indicators. The lack of a clear definition and proper measurement instrument are the main research challenges in the field of precarious employment (Benach and Muntaner 2007). Slovenian researchers (Kresal Šoltes, Strban, and Domadenik 2020) came to a similar conclusion 
and accordingly defined precarious work as work marked by insecurity, whereby insecurity is not a result of a worker's free choice and the work is so intense it represents a risk to the worker's health and wellbeing, and this is one of the premises for our study presented below.

In Slovenia, atypical types of work, which may include elements of precariousness, have lately been particularly evidenced for young adults (1840 years old), as their shares of fixed-term and part-time employment are among the highest in the European Union (Kanjuo Mrčela and Ignjatović 2015), and they are also at the forefront in terms of working as sole proprietors (Domadenik and Redek 2020). This is why the phenomenon of precarious work and mental health is studied in this population upon their entry into the labour market.

This article includes a presentation of the fundamental features of precarious work, followed by its relationship to selected mental health factors in young adults and a presentation of research and results, which is the basis of our discussion and conclusion preparation.

\section{Labour Market Precariousness Features}

The socioeconomic and political change that started at the end of the 1970 led to the collapse of the normative employment model; standard types of employment with indefinite duration contracts, regular and 'sufficient' pay and employment rights being replaced by insecure and flexible types of employment and work (Standing 2011). This increase in labour market flexibility has been justified as a necessary action to preserve jobs, but it decreases job security (Standing 2011; Brady and Biegert 2017; Kresal 2020). Despite the lack of clarity with regard to a definition of precarious work, certain basic features are evidenced. In general, precarious work enables employers to transfer risks and responsibilities to workers, and is marked by various levels and degrees of the objective and subjective features of unreliability and insecurity (International Labour Organization 2011).

Although precarious work takes various forms, it is usually defined in terms of insecurity regarding employment duration, a higher number of possible employers, concealed employment relationships, lower levels of social security and benefits usually connected to employment, lower income, and legal and practical obstacles to trade union association (International Labour Organization 2011; Vives et al. 2011). Precarious workers are in weaker labour and social positions, and have poorer security networks and bases; they also have fewer possibilities for in-house training 
and promotion. This is often accompanied by periods of unemployment and possibly higher personal and family life planning uncertainty (Meehan and Strauss 2015; Eichhorst and Tobsch 2017). The increasing number of precarious types of employment coincides with the increasing risk of poverty. It is furthermore connected to the phenomenon of poor workers, as such work does not always enable a decent living (Van Lancker 2013; OECD 2015). Precarious workers often face financial and employment insecurity. Their income is lower, so they are often uncreditworthy, and face difficulty attaining independence, planning families and purchasing real estate, and this instability does not enable them to plan their lives in the long term (International Labour Organization 2011).

In the last two decades, Slovenian legislation has increasingly supported flexible employment practices. As a result, employment and security protection is weaker, and the number of precarious types of work has increased (Domadenik et al. 2020). For certain workers, increasing employment flexibility means that their social security, rights and autonomy are reduced. Their ability to defend their own rights are severely weakened, and in this way their futures become increasingly insecure and risky (Smolej 2009). The prevailing basic type of work in Slovenia is still indefinite duration employment, although an increasing trend and incidence of atypical types of employment and other types of work that may contain elements of precariousness have been seen in recent years (Laporšek, Franca, and Arzenšek 2018; Domadenik and Redek 2020). This particularly applies to young adults, as their shares of fixed-term and parttime employment are among the highest in the European Union (Kanjuo Mrčela and Ignjatović 2015), and they are also at the forefront in terms of working as sole proprietors (Domadenik and Redek 2020); and this is why we decided to analyse the precarious work phenomenon in relation to mental health in young adults aged 18-40 years who face this when entering the labour market.

\section{Precariousness and Mental Health: Literature Review}

Exposure to insecure types of work may negatively affect an individual's physical and mental health (Jonsson et al. 2020; Employment Conditions Knowledge Network 2010; Vives et al. 2020). Precarious work affects health by means of various mechanisms, including stress at the workplace (Vives et al. 2013), social and material deprivation (Domadenik et al. 2020; Benach and Muntaner 2007), personal life limits, such as the inability to plan for the future (Clarke et al. 2007), dangerous work envi- 
ronments (Benach and Muntaner 2007), low work and safety standards (Quinlan, Mayhew, and Bohle 2001), periods of unemployment, employment pressure because in most cases they must continuously look for new work (Clarke et al. 2007), and presentism (Virtanen et al. 2005). The incidence of many health issues related to the various types of work including elements of precariousness is also confirmed by the findings of a Slovenian study by Domadenik et al. (2020), which found that such workers often report mental health issues, with digestive disorders and disease being very common.

Many studies on the harmful effects of unstable employment on the health of individuals have been conducted. Job instability has been primarily assessed using two approaches, the first being perceived job security, that is, general anxiety regarding the continued existence of jobs in the future (De Witte 1999) in relation to atypical, conditional and nonstandard temporary employment (Virtanen, Janlert, and Hammarström 2011; Quinlan, Mayhey, and Bohle 2001). Such studies have evidenced a consistent connection between job instability and various health conditions, especially weakened mental health. Although job instability is one of the main features of precariousness, studies in the context of unstable work have some important conceptual limitations, which is why their outcomes cannot be fully applied to precarious work (Vives et al. 2013; Vives et al. 2020). This one-dimensional approach is inappropriate because precarious work is a multidimensional construct (Kalleberg 2014; Broughton, Green, and Rickard 2016; Benach et al. 2016), which does not necessarily or merely include job instability. To be more precise, standard employment is often identified as the ideal employment standard and as such precariousness in such types of employment is often underestimated and overlooked (Employment Conditions Knowledge Network 2007; Julia et al. 2017; Vives et al. 2020), and elements of precariousness may also appear in such types of employment.

Based on our review of articles in the field of unstable types of work, including those relating to precariousness and mental health, we have included four mental health constructs in our study, namely life satisfaction, depression, anxiety and emotional exhaustion (Llosa et al. 2018). Empirical data evidences that subjective wellbeing and increased life satisfaction improve mental health and work performance. A high level of satisfaction with life and positive emotions, such as happiness, are connected to a large spectrum of important life factors related to physical and mental health, and social relationships (Pavot and Diener 2008). The 
young adults in different European social security systems doing precarious work reported lower life satisfaction in a study conducted by Vancea, Shore, and Utzet (2018). A negative connection between insecure types of work and life satisfaction was confirmed in a study which researched the connection between life satisfaction and resilience pertaining to stress resulting from unstable types of work (Mauno, Ruokolainen, and Kimnunen 2013). The fact that unstable types of work negatively affect life satisfaction was also confirmed by Silla et al. (2009).

Based on such empirical findings, we assumed that young adults engaged in precarious work would report lower life satisfaction when compared to workers engaged in non-precarious work ( $\mathrm{H} 1)$.

There is no single explanation for the relationship between insecure work and depression and anxiety thus far. D'Souza et al. (2003) evidenced that insecure work is positively related to the incidence of depression and anxiety as did Boya et al. (2008) when they researched the effects of perceived work insecurity on the incidence of depression and anxiety symptoms. Moreover, participants with insecure work achieved higher scores on the Depressions Scale than they did on the Anxiety Scale (Boya et al. 2008). Researchers have also stated that work insecurity may be more stressful and harmful than unemployment (Llosa et al. 2018). In a study by Nella et al. (2015), workers with high levels of work insecurity reported higher levels of perceived stress, anxiety, depression and negative emotions compared to workers in more stable types of employment; as many as $97 \%$ of the workers engaged in insecure types of work reported anxiety symptoms and $86 \%$ depression symptoms.

De Cuyper et al. (2012) researched and analysed the connection between insecure work and emotional exhaustion in terms of perceived external employability, which refers to workers' beliefs on how simple it is to find a new job with another employer, finding a causal link between perceived external employability, insecure work and emotional exhaustion, thereby confirming that insecure work affects emotional exhaustion incidence.

Insecure work reduces welfare by increasing emotional exhaustion, as those engaged in such work believe they have no control over the inherent dangerous working conditions. This corresponds to Stress Coping Theory and findings in the field of insecure work thus far. Workers who perceive their employment situation as insecure, the 'primary rating' being threat, most likely assess their ability to manage such dangerous working environments as insufficient, the 'secondary rating, which might lead to 
lower welfare and increased emotional exhaustion incidence (Vander Elst et al. 2014).

Based on the findings of the above research, we assumed that individuals involved in precarious forms of work will report a higher incidence of symptoms of anxiety and depression ( $\left.\mathrm{H}_{2}\right)$ and emotional exhaustion (H3) compared to employees in non-precarious forms of work.

\section{Method}

PARTICIPANTS

The study included 201 participants from Slovenia, a quarter of whom were men and three quarters women. A condition for participation in the study was that they were aged between 18 and 40 years old, as our focus was the early adulthood period. Another condition was that they were engaged in one of the types of work we were studying. The majority, $42.3 \%$, were aged between 26 and 30 years old, and just over a third were aged between 18 and 25 years old; the smallest group, that is, a tenth of our participants, were aged between 36 and 40 years old. $35.3 \%$ of our participants had indefinite duration contracts, $30.8 \%$ had student contracts and $17.9 \%$ had fixed-term employment contracts. $47.3 \%$ of our sample stated that the type of work they performed was precarious.

\section{MEASUREMENT}

The first scale we use is the Satisfaction with life scale - sLws (Diener et al. 1985), which is designed to measure an individual's overall life satisfaction by means of representing cognitive life satisfaction. It consists of five items that individuals assess on a 1-7 scale (from 1 - strongly disagree to 7 - strongly agree). All scale items are positively oriented and the final result is the sum of the five item scores. The range of the achieved scores is 5 to 35 , whereby a score of 20 is neutral. The life satisfaction scale has a high coefficient of internal consistency measure, with values in studies ranging from 0.79 to 0.89 , pointing to the scale's good reliability. The authors of the scale evidence its good reliability in time as: test-retest $=$ 0.54-0.84 (Pavot and Diener 2008).

We measured depression and anxiety using the Depression Anxiety Stress Scale - DAss-42 (Lovibond and Lovibond 1995), which is composed of 42 items designed to measure depression, anxiety and stress. Individuals give their answers on a four-level scale, from o - does not apply to me at all (never) to 3 - applies to me very much or most of the 
TABLE 1 Research Participant Characteristics

\begin{tabular}{llrr}
\hline Variable & Category & $(1)$ & $(2)$ \\
\hline Gender & Male & 52 & 25.9 \\
& Female & 149 & 74.1 \\
\hline Age & $18-25$ & 70 & 34.8 \\
& $26-30$ & 85 & 42.3 \\
& $31-35$ & 26 & 12.9 \\
& $36-40$ & 20 & 10.0 \\
\hline Type of work & Indefinite duration contract & 71 & 35.3 \\
& Fixed-term contract & 36 & 17.9 \\
& Civil contract & 5 & 2.4 \\
& Sole proprietor & 15 & 7.5 \\
& Part-time contract & 4 & 2.0 \\
& Student work & 62 & 30.8 \\
& Other & 8 & 4.0 \\
\hline Precariousness & Yes & 95 & 47.3 \\
& No & 106 & 52.7 \\
\hline
\end{tabular}

NOTES Column headings are as follows: (1) number of participants, (2) percentage. Under other types of work, participants stated undeclared work (2.5\%), self-employed person in culture (1\%), and managing an association concluding contracts with companies for the purpose of performing work (0.5\%).

time (almost always). Each of the scales includes 14 items; for the purpose of our research, we only used items from the scale for depression and anxiety, by which participants assess the presence of various symptoms for the previous week. The scale is not intended to assess presence or absence of a disorder, but to assess intensity and occurrence of symptoms, and monitor treatment progress (Henry and Crawford 2005). The internal consistency coefficient of the depression scale is 0.96 , whereas it is slightly lower for the anxiety level at 0.89 (Lovibond and Lovibond 1995).

The last component of our mental health model is emotional exhaustion, which we measured using the Maslach Burnout Inventory - M B I (Maslach, Jackson, and Leiter 1997). This scale measures burnout in the workplace based on three dimensions: emotional exhaustion, depersonalisation and personal accomplishment, and is composed of 44 items; for the purpose of our research work, we focused solely on the emotional ex- 
haustion component. In the first part, respondents score the frequency with which they experience the researched feelings on a scale from 1 (a few times a year) to 6 (every day); intensity of experience is scored in the second part, from 1 (very weak) to 7 (very strong); in both cases, 0 can be selected, meaning that respondents have never experienced such feelings (Lamovec 1994). The reliability coefficients for individual scales range from 0.76 to 0.90 , and of the three scales, the emotional exhaustion scale has the best reliability measure at $\alpha=0.90$ (Maslach, Jackson, and Leiter 1997).

Pursuant to the absence of an instrument to measure precariousness, we provided the respondents with a short basic definition of precariousness and they accordingly stated whether they considered their work precarious or not, our definition of precarious work being: Precarious work is unreliable, of a small scale, temporary and legally not protected in the sense of the accompanying rights (the right to a minimum pay, break, holiday leave, social security contributions, etc.). Using the general definition of precariousness, on the basis of which individuals judged the precariousness of their own work, we investigated the subjective assessment of working conditions faced by individuals, as the subjective perception of working conditions determines the well-being and behaviour of individuals.

\section{PROCEDURES}

We customized the scales of the online survey platform Enka (www.1ka.si) accordingly for our purposes. We activated the questionnaire for our survey between May and August 2020 to avoid distorted results pursuant to the current pandemic. We invited participants to cooperate by means of various online social media platforms. First, we posted it on the Facebook group Through the Eyes of Precariousness; soon afterwards, we posted and shared it on Delozlom on Instagram, which has around ten thousand followers. Sampling was executed according to the voluntary participation principle and included a random sample of participants. The conditions for participating in the study were relevant work type participation and ages between 18 and 40. The data was arranged and analysed using Microsoft Excel and spss Statistics 27.0.

\section{Results}

We also assessed how individuals defined precariousness in the context of different types of work to better understand study participant features 
TABLE 2 Precarious Elements within Different Types of Work (in \%)

\begin{tabular}{lrrr}
\hline Type of work & $(1)$ & $(2)$ & $(3)$ \\
\hline Indefinite duration contract & 5.5 & 29.8 & 35.5 \\
Fixed-term contract & 6.0 & 11.9 & 17.9 \\
Civil contract & 2.5 & 0.0 & 2.5 \\
Self-employed & 6.0 & 1.5 & 7.5 \\
Part-time & 1.5 & 0.5 & 24.0 \\
Student work & 23.3 & 7.5 & 30.8 \\
Other & 2.5 & 1.5 & 4.0 \\
Total & 47.3 & 52.7 & 100.0 \\
\hline
\end{tabular}

NOTES Column headings are as follows: (1) precariousness, (2) no precariousness, (3) total. Under other types of work, participants stated undeclared work (2.5\%), selfemployed person in culture (1\%), and managing an association concluding contracts with companies for the purpose of performing work (0.5\%).

(table 2). The majority of our participants, that is, $23.3 \%$ of the student workers, believed that their work included elements of precariousness; such elements were also found in work by means of indefinite duration contracts $(5.5 \%) ; 6 \%$ of participants on a fixed-term contract stated that the type of work they carried out included elements of precariousness; and most of the individuals working on civil contracts stated their work included elements of precariousness, as did sole proprietors.

Table 3 shows data on types of work according to age group. The majority of those aged between 18 and 25 years old carry out student work (23.8\%), with slightly fewer regularly employed in other types of work. Older groups evidence slightly different trends. Those aged between 26 and 30 years old have increased rates of fixed-term employment (11.9\%) and indefinite period employment $(17.9 \%)$, with others being sole proprietors (3\%) and student workers ( $7 \%)$, and this share is significantly lower than that for the previous age group. Among older participants, a notably higher number of people with indefinite duration employment is evidenced, that is, $8.5 \%$ for those aged between 31 and 35 years old, and $6 \%$ for those aged between 36 and 40 years old, who also evidence a dramatic decrease in fixed-term employment when compared to those aged between 26 and 30 years old.

We used spss Statistics 27.0 to evaluate the internal consistency measures, i.e. reliability, of the individual scales used (table 4 ), whereby the Emotional Exhaustion Scale proved most reliable at $\alpha=0.965$. A high in- 
TAB LE 3 Types of Work According to Age Group (in \%)

\begin{tabular}{lrrrrr}
\hline Type of work & $(1)$ & $(2)$ & $(3)$ & $(4)$ & $(5)$ \\
\hline Indefinite duration contract & 3.0 & 17.9 & 8.4 & 6.0 & 35.5 \\
Fixed-term contract & 3.5 & 11.9 & 1.0 & 1.5 & 17.9 \\
Civil contract & 0.0 & 1.0 & 0.2 & 1.0 & 2.5 \\
Self-employed & 2.0 & 3.0 & 2.0 & 0.5 & 7.5 \\
Part-time contract & 1.0 & 0.5 & 0.0 & 0.5 & 2.0 \\
Student work & 23.8 & 7.0 & 0.0 & 0.0 & 30.8 \\
Other & 1.5 & 1.0 & 1.0 & 0.5 & 4.0 \\
Total & 34.8 & 42.3 & 12.9 & 10.0 & 100.0 \\
\hline
\end{tabular}

NOT ES Column headings are as follows: (1) 18-25 years, (2) 26-30 years, (3) 31-35 years, (4) 36-40 years, (5) total. Under other types of work, participants stated undeclared work (2.5\%), self-employed person in culture (1\%), and managing an association concluding contracts with companies for the purpose of performing work (0.5\%).

TAB LE 4 Measures of Internal Consistency of Scales Used

\begin{tabular}{lrrr}
\hline Type of work & $(1)$ & $(2)$ & $(3)$ \\
\hline Life satisfaction & 0.839 & 0.851 & 5 \\
Depression & 0.960 & 0.961 & 27 \\
Anxiety & 0.958 & 0.958 & 26 \\
Emotional exhaustion & 0.965 & 0.966 & 18 \\
\hline
\end{tabular}

Notes Column headings are as follows: (1) Cronbach's alpha coefficient, (2) standardized Cronbach's alpha coefficient, (3) number of items.

ternal consistency coefficient was achieved by the scales for depression at $\alpha=0.960$ and anxiety at $\alpha=0.958$.

We conducted the Kolmogorov-Smirnov normality test prior to testing our hypotheses and the coefficient for all variables used was less than 0.05 , pointing to the fact that our data is not normally distributed, which is why we used the nonparametric Mann-Whitney $U$ test for further analysis and because we are interested in differences between individuals who reported precarious work and those who believed their work did not include elements of precariousness. The use of the Mann-Whitney $U$ test was most appropriate for testing the research hypotheses. Table 5 shows statistically important differences in the variables related to life satisfaction $(p=0.025)$, depression $(p=0.004)$, anxiety $(p=0.011)$ and emotional exhaustion $(p=0.000)$. We can see that the participants who state their work had features of precarious work achieved lower results in relation to 
TA B LE 5 Test Statistics: Mann-Whitney U Test and Individual Scale Range Values

\begin{tabular}{lcrrrrr}
\hline Variable & $(1)$ & $(2)$ & $(3)$ & $(4)$ & $(5)$ & $(6)$ \\
\hline Life satisfaction & Yes & 95 & 91.29 & 8673.00 & 4113.000 & 0.025 \\
& No & 106 & 109.70 & 11628.00 & & \\
\hline Depression & Yes & 95 & 113.40 & 10773.00 & 3857.000 & 0.004 \\
& No & 106 & 89.89 & 9528.00 & & \\
\hline Anxiety & Yes & 95 & 111.96 & 10636.00 & 3994.000 & 0.011 \\
& No & 106 & 91.18 & 9665.00 & & \\
\hline Emotional exhaustion & Yes & 95 & 116.85 & 11100.50 & 3529.500 & 0.000 \\
& No & 106 & 86.80 & 9200.50 & & \\
\hline
\end{tabular}

NOTES Column headings are as follows: (1) precariousness, (2) number of participants, (3) range average, (4) range sum, (5) $U$-test, (6) $p$ - level of properties $(p \leq 0.05)$.

life satisfaction compared to those who did not report the presence of precariousness elements in the type of work they performed; furthermore, they achieved higher results in relation to depression, anxiety and emotional exhaustion. Our results highlight the higher presence of symptoms related to depression and emotional exhaustion.

\section{Discussion and Conclusion}

Precariousness can indirectly affect health by means of various psychological and behavioural coping mechanisms (Vives et al. 2013). The presence of 'chronic' employment insecurity is often connected to psychosocial stress reactions, leading to poorer physical and mental health (D'Souza et al. 2003; Jonsson et al. 2020; Employment Conditions Knowledge Network 2010; Vives et al. 2020); it may also cause problems in terms of social inclusion, as such workers have difficulty socialising with people from their social environment because of their poorly distributed working times, leading to them often feeling socially isolated (Domadenik et al. 2020). The companies with policies to employ workers for longer periods of time and willing to provide stable employment offer better working environments. Workers with indefinite duration contracts are better affiliated to employers and more productive, and have better relationships. Workers constantly worried about whether they will earn enough to survive spend a great deal of time looking for regular employment and other income, and find it difficult to identify with the companies they work for. Weaker affiliation to employers and co-workers affects relationships as well as productivity (Brinkmann et al. 2006). 
Pursuant to previous findings, we assumed that individuals engaged in precarious work would report lower life satisfaction ( $\mathrm{H} 1)$, higher occurrence of anxiety and depression symptoms ( $\left.\mathrm{H}_{2}\right)$ and emotional exhaustion ( $\mathrm{H}_{3}$ ) when compared to workers engaged in non-precarious work. Our research results evidence statistically important differences between the two groups. Young adults engaged in precarious work on average achieved lower scores for life satisfaction, highlighting poorer life satisfaction. Our research results are consistent with the findings of previous studies in the field of insecure/unstable work and life satisfaction, that is, subjective wellbeing (Hsieh and Huang 2017; Mauno, Ruokolainen, and Kinnunen 2013; Vancea, Shore, and Utzet 2018), meaning that young adults engaged in precarious work report importantly lower levels of quality of life and perceived life satisfaction is an important element of mental health self-rating.

The correlation between depression and anxiety symptoms with precarious work incidence has been highlighted in several studies (D'Souza et al. 2003; Llosa et al. 2018; Toivanen et al. 2020; Wang et al. 2009; Wang et al. 2011). Our second hypothesis is also confirmed because the young adults who stated their work included elements of precariousness achieved higher scores on the depression and anxiety scales compared to the young adults who did not report the presence of elements of precariousness. Constant worry about monthly income, looking for future employment and a wide range of social and personal issues, including finding an apartment, day-care for children, and maintaining friendships and romantic relationships, harmfully affect the physical and emotional health of those engaged in precarious work. Many precarious workers report experiencing several health issues, such as stomach problems, sleep disorders and high blood pressure, and an important proportion of such workers report anxiety and depression issues directly attributable to their employment (Clarke et al. 2007).

Our final mental health dimension, emotional exhaustion, is the central element of burnout, and we evidenced statistically important difference in relation to the groups of young adult worker participants to confirm our third hypothesis. Precarious workers evidenced higher scores on the emotional exhaustion scale when compared to workers who did not report the presence of elements of precariousness. This is consistent with the findings of De Cuyper et al. (2012), who found that insecure work positively influences emotional exhaustion occurrence.

Based on our results for the second and third hypotheses, a question 
arises as to whether society as a whole really benefits from precarious work in terms of business savings being reflected in increased public health system expenditure: those whose health is damaged due to their work are forced to seek medical and psychological help several times at different levels, thereby further burdening health systems. Emotional exhaustion also reduces activity in other spheres of life, which increases the possibility of emotionally exhausted individuals being less actively involved in family and social processes. Other studies correlate insecure work with sleep disorders (Boya et al. 2008; Toivanen et al. 2020), anxiety and depression (D'Souza et al. 2003; Toivanen et al. 2020; Wang et al. 2009; Wang et al. 2011), psychosomatic stress symptoms (Mauno and Kinnunen 2002), family relationship problems, a lack of motivation, weaker immune systems, exhaustion and dissatisfaction with work (Boya et al. 2008).

A major limitation of this study is the lack of a suitable measurement instrument for precariousness. Spanish researchers developed The Employment Precariousness Scale (E P R E S) (Vives et al. 2011; Vives et al. 2013) to measure employment precariousness. An additional limitation arising from the lack of a measurement instrument is that participants had to assess the precariousness of their own employment based on the general definition provided in our survey; we trusted their self-assessment but should nevertheless ask ourselves about the actual precarious work situation.

The next limitation is the uneven distribution of participants according to gender, age and type of work, and this should be eliminated in the future to obtain the most realistic image of sample properties related to work precariousness as possible, including theoretical sampling of participants with certain properties; dedicated sampling would be of the greatest utility, as it would facilitate the selection of more appropriate participants (Hlebec and Mrzel 2012).

In summation, precarious work is a broad phenomenon and there is no universally accepted definition. Our research findings evidence that precarious work plays an important role in life satisfaction, including depression, anxiety and emotional exhaustion symptom occurrence. The young adults who assessed their work as precarious are not satisfied with their lives, do not understand it as well as they could, and do not balance their aspirations and values. Life satisfaction as a component of subjective wellbeing is important because it may beneficially affect an individual's mental health. We found a negative correlation between life satisfaction 
and depression development: respondents who ranked their work as precarious reported a higher presence of depression symptoms, which may eventually lead to depression disorder development. We also researched anxiety symptom development and it was reported more by participants engaged in precarious work. Such workers largely suffer emotional exhaustion resulting from the extreme emotional requirements of their precarious work. Results show that such individuals face feelings of being overburdened and exhausted because they are often stressed and highly agitated.

The need for such research is great, as the phenomenon of atypical types of employment which may lead to precariousness has been on the rise, no more so than in Slovenia, which lacks sufficient research on this pressing topic. First of all, a step forward must be taken to recognise and measure precarious types of work. Furthermore, we have found that the current epidemiological situation has further increased the burden carried by workers engaged in precarious work, as they are generally the first ones to lose their jobs in crisis situations, and the current crisis is no different in this regard.

\section{References}

Allan, B. A., K. L. Autin, and K. G. Wilkins-Yel. 2021. 'Precarious Work in the 21st Century: A Psychological Perspective.' Journal of Vocational Behavior 126:103491. https://doi.org/10.1016/j.jvb.2020.103491.

Benach, J., and C. Muntaner. 2007. 'Precarious Employment and Health: Developing a Research Agenda.' Journal of Epidemiology and Community Health 61 (4): 276-7.

Benach, J., A. Vives, G. Tarafa, C. Delclos, and C. Muntaner. 2016. 'What Should We Know About Precarious Employment and Health in 2025? Framing the Agenda for the Next Decade of Research.' International Journal of Epidemiology 45 (1): 232-8.

Boya, F. Ö., Y. Demiral, A. Ergör, Y. Akvardar, and H. De Witte. 2008. 'Effects of Perceived Job Insecurity on Perceived Anxiety and Depression in Nurses.' Industrial Health 46 (6): 613-9.

Brady, D. and T. Biegert. 2017. 'The Rise of Precarious Employment in Germany.' soe ppaper 936, The German Socio-Economic Panel Study, Berlin. http://dx.doi.org/10.2139/ssrn.3099401.

Brinkmann, U., K. Dörre, S. Röbenack, K. Kraemer, and F. Speidel. 2006. Prekäre Arbeit: Ursachen' Ausmaß soziale Folgen und Subjektive Verarbeitungsformen unsicherer Beschäftigungsverhältnisse. Bonn: FriedrichEbert-Stiftung. 
Broughton A., M. Green, and C. Rickard. 2016. Precarious Employment in Europe; Part 1: Patterns, Trends and Policy Strategies. Brussels: European Parliament.

Clarke, M., W. Lewchuk, A. de Wolff, and A. King. 2007. “'This Just Isn't Sustainable:" Precarious Employment, Stress and Workers' Health.' International Journal of Law and Psychiatry 30 (4-5): 311-26.

De Cuyper, N., A. Mäkikangas, U. Kinnunen, S. Mauno, and H. De Witte. 2012. 'Cross-Lagged Associations between Perceived External Employability, Job Insecurity, and Exhaustion: Testing Gain and Loss Spirals According to the Conservation of Resources Theory.' Journal of Organizational Behavior 33 (6): 770-88.

Debels, A. 2008. 'Transitions out of Temporary Jobs: Consequences for Employment and Poverty across Europe.' In Flexibility and Employment Security in Europe: Labour Markets in Transition, edited by R. Muffels, 51-77. Cheltenham: Edward Elgar.

De Witte, H. 1999. 'Job Insecurity and Psychological Well-Being: Review of the Literature and Exploration of Some Unresolved Issues.' European Journal of Work and Organizational Psychology 8 (2): 155-77.

Diener, E. D., R. A. Emmons, R. J. Larsen, and S. Griffin. 1985. 'The Satisfaction with Life Scale.' Journal of Personality Assessment 49 (1): 71-5.

Domadenik, P., S. Bagari, V. Franca, T. Redek, and L. Rihter. 2020. 'Empirična analiza prekarnosti na trgu dela v Sloveniji.' In Prekarno delo: multidisciplinarna analiza, edited by K. Kresal Šoltes, G. Strban, and P. Domadenik, 263-8o. Ljubljana: Pravna fakulteta in Ekonomska fakulteta.

Domadenik, P., and T. Redek. 2020. 'Primerjava stanja na trgu dela in pojavnosti prekarnosti v Sloveniji in državah E U.' In Prekarno delo: multidisciplinarna analiza, edited by K. Kresal Šoltes, G. Strban, and P. Domadenik, 183-211. Ljubljana: Pravna fakulteta in Ekonomska fakulteta.

D'Souza, R. M., L. Strazdins, L. Y. Lim, D. H. Broom, and B. Rodgers. 2003. 'Work and Health in a Contemporary Society: Demands, Control and Insecurity.' Journal of Epidemiology and Community Health 57 (11): 849-54.

Eichhorst, W., and T. Tobsch. 2017. Risk of Precariousness: Results from European Working Conditions Survey 2010 and 2015. Brussels: European Parliament.

Employment Conditions Knowledge Network. 2007. 'Employment Conditions and Health Inequalities: A Global Perspective.' https://www.who .int/social_determinants/resources/articles/emconet_who_report.pdf. - 2010. 'Unemployment, Informal Work, Precarious Employment, Child Labor, Slavery and Health Inequalities: Pathways and Mechanisms.' International Journal of Health Services 40 (2): 281-95. 
Eurofound. 1998. Precarious Employment and Working Conditions in Europe. Luxembourg: Office for Official Publications of the European Communities.

Forde, C., and G. Slater. 2006. 'The Nature and Experience of Agency Working in Britain: What are the Challenges for Human Resource Management?' Personnel Review 35 (2): 141-57.

Gash, V., A. Mertens, and L. R. Gordo. 2007. 'Are Fixed-Term Jobs Bad for Your Health? A Comparison of West-Germany and Spain.' European Societies 9 (3): 429-58.

Glavin, P. 2013. 'The Impact of Job Insecurity and Job Degradation on the Sense of Personal Control.' Work and Occupations 40 (2): 115-42.

Henry, J. D., and J. R. Crawford. 2005. 'The Short-Form Version of the Depression Anxiety Stress Scales (DAss-21): Construct Validity and Normative Data in a Large Non-Clinical Sample.' British Journal of Clinical Psychology 44 (2): 227-39.

Hlebec, V., and M. Mrzel. 2012. 'Metodološke dileme in njihove rešitve v raziskovalnem načrtu $\mathrm{z}$ zaporedno uporabo kvantitativnih in kvalitativnih metod - model izbire udeležencev'. Teorija in praksa 44 (2): 24563.

Hsieh, H. H., and J. T. Huang. 2017. 'Core Self-Evaluations and Job and Life satisfaction: The Mediating and Moderated Mediating Role of Job Insecurity'. The Journal of Psychology 151 (3): 1-17.

International Labour Organization. 2011. Policies and Regulations to Combat Precarious Employment. Geneva: International Labour Office.

Jeriček Klanšček, H., K. Hribar, and M. Bajt. 2017. Skrb za duševno zdravje tudi na delovnem mestu. Ljubljana: Nacionalni inštitut za javno zdravje. Jetha, A., K. A. Martin Ginis, S. Ibrahim, and M. A. M. Gignac. 2020. 'The Working Disadvantaged: The Role of Age, Job Tenure and Disability in Precarious Work.' вмс Public Health 20. https://link.springer.com/ article/10.1186/s12889-020-09938-1.

Jonsson, J., N. Matilla-Santander, B. Kreshpaj, G. Johansson, K. Kjellberg, B. Burström, and T. Bodin. 2020. 'Precarious Employment and General, Mental and Physical Health in Stockholm, Sweden: A CrossSectional Study' Scandinavian Journal of Public Health 49 (2): 228-36.

Julia, M., C. Vanroelen, K. Bosmans, K. Van Aerden, and J. Benach. 2017. 'Precarious Employment and Quality of Employment in Relation to Health and Well-Being in Europe.' International Journal of Health Services 47 (3): 389-409.

Kalleberg, A. L. 2014. 'Measuring Precarious Work'. A Working Paper of the EINet Measurement Group, EIEnet, Chicago. https://cpb -us-w2.wpmucdn.com/voices.uchicago.edu/dist/5/1068/files/2018/05/ einet_papers_kalleberg-1owgfyz.pdf. 
Kanjuo Mrčela, A., and M. Ignjatović. 2015. 'Od prožnosti do prekarnosti dela: stopnjevanje negativnih sprememb na začetku 21. stoletja.' Teorija in praksa 52 (3): 350-81.

Kresal, B. 2020. 'Vpliv prekarizacije dela na individualne pravice delavcev.' In Prekarno delo: multidisciplinarna analiza, edited by Kresal Šoltes, K., G. Strban, and P. Domadenik, 15-28. Ljubljana: Pravna fakulteta in Ekonomska fakulteta.

Kresal Šoltes, K., G. Strban, and P. Domadenik. 2020. 'Predgovor.' In Prekarno delo: multidisciplinarna analiza, edited by Kresal Šoltes, K., G. Strban, and P. Domadenik, 9-12. Ljubljana: Pravna fakulteta in Ekonomska fakulteta.

Kreshpaj, B., C. Orellana, B. Burström, L. Davis, T. Hemmingsson, G. Johansson, K. Kjellberg, J. Jonsson, D. H. Wegman, and T. Bodin. 2020. 'What is Precarious Employment? A Systematic Review of Definitions and Operationalizations from Quantitative and Qualitative Studies.' Scandinavian Journal of Work, Environmnent and Health 46 (3): 23547.

Lam, J., W. Fan, and P. Moen. 2014. 'Is Insecurity Worse for Well-Being in Turbulent Times? Mental Health in Context.' Society and Mental Health 4 (1): 55-73.

Lamovec, T. 1994. Psihodiagnostika osebnosti 1. Ljubljana: Znanstveni inštitut Filozofske fakultete.

Laporšek, S., V. Franca, and A. Arzenšek. 2018. 'Kako dostojne so nove oblike dela v Sloveniji?' Economic and Business Review 20 (Special Issue): 129-45.

Llosa, J. A., S. Menéndez-Espina, E. Agulló-Tomás, and J. RodríguezSuárez. 2018. 'Job Insecurity and Mental Health: A Meta-Analytical Review of the Consequences of Precarious Work in Clinical Disorders.' Anales de Psicología 34 (2): 211-23.

Lovibond, P. F., and S. H. Lovibond. 1995. 'The Structure of Negative Emotional States: Comparison of the Depression Anxiety Stress Scales (DAss) with the Beck Depression and Anxiety Inventories.' Behaviour Research and Therapy 33 (3): 335-43.

Mai, Q. D., A. W. Jacobs, and S. Schieman. 2019. 'Precarious Sleep? Nonstandard Work, Gender, and Sleep Disturbance in 31 European Countries.' Social Science \& Medicine 237 (5): 112424. https://doi.org/10.1016/j .socscimed.2019.112424.

Maslach, C., S. E. Jackson, and M. P. Leiter. 1997. 'Maslach Burnout Inventory: Third Edition.' In Evaluating Stress: A Book of Resources, edited by C. P. Zalaquett and R. J. Wood, 191-218. Lanham: Scarecrow Education.

Mauno, S., and U. Kinnunen. 2002. 'Perceived Job Insecurity among DualEarner Couples: Do Its Antecedents Vary According to Gender, Eco- 
nomic Sector and the Measure Used?' Journal of Occupational and Organizational Psychology 75 (3): 295-314.

Mauno, S., M. Ruokolainen, and U. Kinnunen. 2013. 'Does Aging Make Employees More Resilient to Job Stress? Age as a Moderator in the Job Stressor-Well-Being Relationship in Three Finnish Occupational Samples.' Aging \& Mental Health 17 (4): 411-22.

Meehan, K., and K. Strauss. 2015. Precarious Worlds: Contested Geographies of Social Reproduction. Athens, GA: University of Georgia Press.

Močnik, R. 2010. 'Delovni razredi v sodobnem kapitalizmu.' In Postfordizem: razprave o sodobnem kapitalizmu, edited by G. Kirn, 149202. Ljubljana: Mirovni inštitut.

Moscone, F., E. Tosetti, and G. Vittadini. 2016. 'The Impact of Precarious Employment on Mental Health: The Case of Italy'. Social Science \& Medicine 158:86-95.

Mrozowicki, A., and V. Trappman. 2021. 'Precarity as a Biographical Problem? Young Workers Living with Precarity in Germany and Poland.' Work, Employment and Society 35 (2): 221-38.

Nella, D., E. Panagopoulou, N. Galanis, A. Montgomery, and A. Benos. 2015. 'Consequences of Job Insecurity on the Psychological and Physical Health of Greek Civil Servants.' BioMed Research International 673623. https://www.doi.org/10.1155/2015/673623.

OECD. 2015. In It Together: Why Less Inequality Benefits All. Paris: OECD Publishing.

Padrosa, E., M. Bolibar, M. Julia, and J. Benach. 2021. 'Comparing Precarious Employment Across Countries: Measurement Invariance of the Employment Precariousness Scale for Europe (E P RES-E).' Social Indicators Research 154 (3): 893-915.

Pavot, W., and E. Diener. 2008. 'The Satisfaction with Life Scale and the Emerging Construct of Life Satisfaction.' The Journal of Positive Psychology 3 (2): 137-52.

Quinlan, M., C. Mayhew, and P. Bohle. 2001. 'The Global Expansion of Precarious Employment, Work Disorganization and Consequences for Occupational Health: A Review of Recent Research.' International Journal of Health Services 31 (2): 335-414.

Silla, I., N. De Cuyper, F. J. Gracia, J. M. Peiró, and H. De Witte. 2009. 'Job Insecurity and Well-Being: Moderation by Employability' Journal of Happiness Studies 10 (6): 739-52.

Smolej, S. 2009. 'Negativne plati fleksibilizacije zaposlovanja - delo za določen čas $\mathrm{v}$ storitvenem sektorju in pojav revščine med zaposlenimi.' Socialno delo 48 (4): 199-206.

Standing, G. 2011. The Precariat. London: Bloomsbury Academic.

Toivanen, S., A. O. Tarantino, M. Emmelin, and P. O. Östergren. 2020. 'Di- 
verting Blame to Stay Sane-Young People's Strategies for Dealing with the Mental Health Effects of Precarious Employment: A Grounded Theory Study'. вMC Public Health 20 (571). https://doi.org/10.1186/s12889020-08626-4.

Utzet, M., E. Valero, I. Mosquera, and U. Martin. 2020. 'Employment Precariousness and Mental Health, Understanding a Complex Reality: A Systematic Review.' International Journal of Occupational Medicine and Environmental Health 33 (5): 569-98.

Valero, E., U. Martin, A. Bacigalupe, and M. Utzet. 2021. 'The Impact of Precarious Jobs on Mental Health: A Gender-Sensitive Literature Review.' International Archives of Occupational and Environmental Health 94 (4): 577-89.

Vancea, M., and M. Utzet. 2017. 'How Unemployment and Precarious Employment Affect the Health of Young People: A Scoping Study on Social Determinants.' Scandinavian Journal of Public Health 45 (1): 73-84.

Vancea, M., J. Shore, and M. Utzet. 2018. 'Role of Employment-Related Inequalities in Young Adults' Life Satisfaction: A Comparative Study in Five European Welfare State Regimes.' Scandinavian Journal of Public Health 1 (9): 1-9.

Vander Elst, T., A. Van den Broeck, N. De Cuyper, and H. De Witte. 2014. 'On the Reciprocal Relationship between Job Insecurity and Employee Well-Being: Mediation by Perceived Control?' Journal of Occupational and Organizational Psychology 87 (4): 671-93.

Van Lancker, W. 2013. 'Temporary Employment and Poverty in the Enlarged European Union: An Empirical and Comparative Analysis.' In Non-Standard Employment in Europe: Work and Welfare in Europe, edited by Koch M. and M. Fritz, 190-208. London: Palgrave Macmillan.

Virtanen, P., U. Janlert, and A. Hammarström. 2011. 'Exposure to Temporary Employment and Job Insecurity: A Longitudinal Study of the Health Effects.' Occupational and Environmental Medicine 68 (8): 5704.

Virtanen, M., M. Kivimäki, M. Joensuu, P. Virtanen, M. Elovainio, and J. Vahtera. 2005. 'Temporary Employment and Health: A Review.' International Journal of Epidemiology 34 (3): 610-22.

Vives, A., M. Amable, M. Ferrer, S. Moncada, C. Llorens, C. Muntaner, and J. Benach. 2013. 'Employment Precariousness and Poor Mental Health: Evidence from Spain on a New Social Determinant of Health.' Journal of Environmental and Public Health 978656. https://doi.org/10.1155/2013 1978656.

Vives, A., T. Benmarhnia, F. González, and J. Benach. 2020. 'The Importance of Using a Multi-Dimensional Scale to Capture the Var- 
ious Impacts of Precarious Employment on Health: Results from a National Survey of Chilean Workers.' PloS One 15 (9): eo238401. https://doi.org/10.1371/journal.pone.0238401.

Vives, A., C. Vanroelen, M. Amable, M. Ferrer, S. Moncada, C. Llorens, and J. Benach. 2011. 'Employment Precariousness in Spain: Prevalence, Social Distribution and Population-Attributable Risk Percent of Poor Mental Health.' International Journal of Health Services 41 (4): 625-46. Wang, J., N. Schmitz, C. Dewa, and S. Stansfeld. 2009. 'Changes in Perceived Job Strain and the Risk of Major Depression: Results from a Population-Based Longitudinal Study'. American Journal of Epidemiology 169 (9): 1085-91.

Wang, J., S. Patten, S. Currie, J. Sareen, and N. Schmitz. 2011. 'Perceived Needs for and Use of Workplace Accommodations by Individuals with a Depressive and/or Anxiety Disorder.' Journal of Occupational and Environmental Medicine 53 (11): 1268-72. 